\title{
Research on the education idea of people-oriented and the application in the sergeant training
}

\author{
Zhang Wujun \\ Dept. of Transportation service, Automobile Sergeant Institute,Bengbu,230011 China \\ wader1982@163.com
}

\begin{abstract}
People-oriented is the need of social development, is a sign of progress of human civilization. Education is the "human spirit" project, is the cradle of all kinds of excellent talents. Keep up with the development of The Times, people-oriented has been introduced into education field in the $1960 \mathrm{~s}$, and gradually carried forward. In the field of military education, with the development of new military revolution, need to have application and practice of the new education idea. Sergeant training is forces of hotspots in the field of education in recent years, how to people-oriented education idea and sergeant training together, is the instructors at all levels should consider the practical problems. This paper is to briefly analyze the basic connotation of the people-oriented education idea, and then based on the "servicing position", "sergeant skills", "the process of training "and "career planning", and the principles of the corresponding to the humanist education idea to a concrete analysis of its application in petty officer training.
\end{abstract}

Index Terms - people-oriented; education idea; sergeant training; application.

\section{Introduction}

"Scientific development" as the guiding ideology has been written to the articles of association of the eighteen Chinese communist meeting, and is going to be as the guiding theoretical foundation of social development for a long time, the core of "Scientific development" is "people-oriented". Education is the "human spirit" project, around the "people" is the career of "influence people, cultivate people, shaping people, achievement ${ }^{,[1]}$. In the recent years the concept of people-oriented and education have been closely combined, formed the people-oriented education idea, and the rapid rise in the domestic, whether it is a teaching management, teaching management personnel or the general teacher's classroom teaching, have in the implement practice of people-oriented education idea, the same is true in the field of military education ${ }^{[2]}$. With the deepened reform of military education, sergeant education had been an important training task and was given in colleges, universities and training institutions, the exploration of education mode was researched, the peopleoriented education idea in sergeant education began to practice in the training too. In this paper, the simple analysis of the basic theory of people-oriented education idea was given, focused on analyzing application in sergeant training.

\section{The basic connotation of people-oriented education idea}

The connotation of people-oriented concept is "Any activity of human society are to satisfy the people's survival and development for the purpose, with its emphasis on people is the main part of the nature, society and themselves; People is the highest value in form ${ }^{[3]}$." Said from macroscopic, the human-oriented education idea is a kind of education orientation in the education activities, it relies on its internal has interrelated principles, content, ideas and the corresponding implementation strategies to protect and support the student self-awareness of their own quality, rebuild themselves and develop their unique personality and selfrealization. Said from the micro, "people-oriented" education, refers to in the process of education by artificial starting point and the center, surrounding the inspire and arouse people's initiative, enthusiasm and creativity, to realize people with education to develop a series of education and teaching activities. The essence of which is focus on personality development of students. In constant guide students in the teaching process, and combined with the characteristics of the students to give them the space of free play, help students to complete the process of self awareness and self expression, so that the students can actively exert their subjective initiative in the teaching process.

Realization of people-oriented education idea has the following basic principles ${ }^{[4,5]}$ :

(1) Principle of self-realization. Each of the students in the learning process will be more or less show their potential or the longing for knowledge, teachers should support and encourage students to continue to dig and develop the interest and ability, so as to realize the value of the students themselves.

(2) The subjectivity of education principles. The connotation embodied in the subjectivity of students in teaching, in the "core" status. In the teaching form, purpose, content, teaching method and so on, to give students the right to choose, to consider their willingness to listen to their advice, so as to achieve according to their aptitude, realizes the student individuality development, the spirit of people-oriented.

(3) Principles of creative education. In the teaching process can be carried out some creative activities, the characteristics of development of each student, to discover their creative potential, helping students to selfimprovement, self discovery.

(4) Principle of education's support and trust. Teachers should fully trust and support to achieve the students self development and self, believe they can correct cognition and can realize their own value, given enough patience, support and trust. 
All in order to implement the people-oriented education idea and teaching methods and strategies should have dialogue and exchanges, and the characteristics of the creative activity, should be for the purpose of students' personality development, provide students with broad space for development, let them to make decisions independently, choice of teaching content, forms and so on. Commonly used teaching methods and means, respectively is: the dialogue teaching, game teaching method, self diagnosis method, the situational teaching method and so on. These methods give the students' performance more space and show chance, highlight the people-oriented spirit.

\section{III . The application of people-oriented education in sergeant training}

A. Conformed to the "servicing position", using the peopleoriented education idea of "self-realization" principle, make sure the training objects, doing the top-level design of training.

Sergeant is the special group of forces, has the "officer" and "soldiers" dual identity, plays an essential role in the army, makes sure to achieve the task of "can fight, winning the fight". Every sergeant has their own jobs, these jobs have the requirements of skills, so training sergeant must be adapted to these requirements. Traditional sergeant job requirements, tend to focus the jobs the content of the content, methods, etc, only consider the job, not considering the job service of officers in some cases, such as the job serving in the army for subsequent development, development of the army, and so on, therefore colleges and universities in the analysis of training object, training the top-level design, training system for post design, no analysis of the specific conditions of the "people". Sergeant works in the post, may be a transfer to other positions or retired after two terms, this requests us in the top-level design, training to use the humanist education idea of "selfrealization" principle, to consider his work in this job and in the later work, interested in what kind of knowledge and skills, how to realize their own value, how to play their own potential, how to realize their life values, and so on. We analysis to these, and through the top-level design, consider how to help the sergeant in the future work and study playing their value of life, realize their life ideal, such design of the training system can truly oriented position, point to the future, can greatly arouse sergeant passion of learning, to achieve "teaches something, to have all, based on now, facing the future".

B. Based on "sergeant skills", using the subjectivity principle of people-oriented education idea, improve the training mode, training implementation.

Current military education process, has been using some of the humanist education idea of "subjectivity principle", for example in the curriculum standards, curriculum design, require standing on the perspective of training object, but a lot just to stand in the word of the first person to stand in the training object of the word of the third person, it may be said "in its form, not really understand the connotation of them." Based on "sergeant skills" truly, is want to be in specific teaching form, purpose, content, teaching methods, such as design, consideration has been training for skills requirements, according to their aptitude, vary from person to person. So, on the training model, cannot be confined to the traditional post what skills are needed to train what skills, but in the object's characteristics, by what the skills training object itself, the various skills of strong and weak, what kind of requirements they have, thus transformed into "consolidation strength, vigorously improve the short board" training mode, change the unified training model of "cramming" to "demand" training mode. In the process of training, we can also according to every sergeant 's own skills, strengths, do pointed to train its weaknesses, can play to their strengths, mutual help, and then improve as a whole. Only in this way station on improving "sergeant skills" the overall goal, gives rights to be trainers, considering their willingness to listen to their advice, design according to different training methods, means and process of the individual, in this way sergeant can in the implementation of training to achieve the effect of "what wanted, what study".

C. Based on "the process of training", using the peopleoriented education idea of "creative" principle, innovative training appraisal method, completes the training evaluation process.

The traditional sense of evaluation is to design a set of skills standards as the basis of the inspection system, considering the various skills, no consideration the trainers individuals.

We should know that, the purpose of training is not skills, but to improve skills, not consider learned many knowledge and skills, but to consider in the process of training, access to the content of the life in his later work. This requests us to examine the creative to design the form of evaluation, using "public justice" principle, basing on the "training process", doing an objective evaluation of the trainers.For example, A feasible evaluation system can be done in the process of training, including training attitude, training improve, etc., for inspection reference; During evaluation, that is, consider the final standards, and consider how much improver than that of before the training. This form of examination, to prevent training skills before the lower sergeant of weariness, practice will not think how good grades, put an end to the claim that before training skills higher sergeant, think don't practice also can get good grades. Anyhow on training evaluation, faculty should undertake creative design, fully arouse the enthusiasm of clearly understood, and to achieve the effect of "process and result".

D. Based on "career planning", using of the people-oriented education idea of "education's support and trust" principle, encourage further self learning, completes the training after the training, improve the process.

Sergeant is training in school or training institutions, training graduation is the end of centralized training, rather than the end of the training, is the starting point of the new 
training. Training is over, sergeant returns to troops to relax the requirements, he don't insist, will slowly forgotten some skills, not a long-term follow-up plans. Giving up an end to this kind of phenomenon, must be in the process of training, especially in the second half, sergeant must be instilled such thoughts, the trust and support after back to the original unit, self learning and self training, to clear oneself in the army and retired the "career planning", believe they can correct cognition and can realize their own value. Only in this way, sergeant after training begins a starting point, better planning their own development, better targeted their own learning and training, teachers can provide remote assistance and guidance at any time, to achieve the effect of "living and learning".

\section{IV . Conclusion}

People-oriented education idea has been widely applied in civil education field, the application in the field of military education has started, has only just started to practice in sergeant training field. People-oriented education idea in sergeant training in the field of application, training instructors at all levels should be in-depth study. For application of how to be more specific, how to evaluate its application, as well as the more modeling application process, is the emphasis of further research.

\section{References}

[1] Xiuying. Wang, "In English teaching how to implement the humanist teaching idea," The new curriculum studies, pp. 30-31, May 2012.

[2] Zhigang. Zhai, "The people-oriented concept of public security training education," Shanxi Province police officer college journals, pp. 22-24, January 2008.

[3] Shaohui. Wu, "Introduction to "people-oriented" education philosophy," High school biology teaching, pp. 42-44, November 2005.

[4] Xumin Wu,"Theory of the practice of "people-oriented" education idea," Chinese teachers, pp. 18-21, April 2007.

[5] Caihui. Lu, "Teaching how to embody the human-oriented education concept,". China's education, pp. 55-56, October 2011 